HOLGER H. HERWIG

\title{
German Policy in the Eastern Baltic Sea in 1918: Expansion or Anti-Bolshevik Crusade?
}

The Bolshevik Revolution in November 1917 offered Germany the first serious prospect of ending the two-front war dilemma. General Erich Ludendorff, anticipating resultant cessation of major military operations in the East, decided to seek a military victory in the West. But the ensuing peace negotiations with the Bolsheviks at Brest-Litovsk revealed basic policy differences within the German camp. Richard Kühlmann, state secretary of the Foreign Office, felt that the Bolshevik victory had sufficiently crippled Russia's armed might and had thereby eased the military burden in the East. Kühlmann as well as his successor, Admiral Paul von Hintze, successfully opposed all proposals to oust the Bolsheviks. Because they both believed that Bolshevik rule would assure long-term chaos in Russia, they sought a compromise peace in the East. The Foreign Office, through the first German ambassadors to Moscow, Count Wilhelm von Mirbach-Harff and Karl Helfferich, even extended financial aid to the Bolsheviks in order to keep them out of the Entente camp. In short, Germany's diplomats possessed a clear conception of their policies regarding the Bolsheviks and were consistent in them, desiring no armed conflict in the East but rather a concentration of military might in the West. The Army Supreme Command, and especially Ludendorff, rejected any compromise formula in the East, despite the decision of November 1917 to seek a military victory in the West. Ludendorff sought to end the war with either victory or defeat. Nonetheless, in the summer of 1918 he proved willing temporarily to accept the plan of the Foreign Office to cooperate with the Bolsheviks and "use" them to attain German goals, a decision that paralleled his original agreement in April 1917 to transport the Bolshevik leaders in Switzerland to Russia. But by the fall of 1918, supported by Generals Max Hoffmann and Rüdiger von der Goltz, he was ready to launch an anti-Bolshevik campaign. The improvised character of Ludendorff's eastern policy is reflected in his adventurous schemes in the Russian "border states" such as the Ukraine, the Crimea, the Caucasus, Georgia, and Finland. His policy in the East possessed no basic concept; inconsistency was its dominant characteristic.

German policy in the Baltic Sea region centered on the civil war in Finland, Bolshevik rule in Russia, and Allied landings in Murmansk. The Kaiser

This project was supported through the Klaus Epstein Memorial Fellowship of the Alexander v. Humboldt-Stiftung. 
and his military aides strongly favored independence for Finland and expulsion of the Allied forces from northern Russia. They were generally agreed to end Bolshevik rule in Russia and to restore the monarchy. Wilhelm II also pursued certain dynastic ambitions in the Baltic area. ${ }^{1}$ The Foreign Office, on the other hand, wanted to fulfill Germany's obligations under the Brest-Litovsk treaty, a policy which they felt would be jeopardized if Germany actively supported anti-Bolshevik movements in Russia's "border states." German naval planners followed yet another course. They steadfastly regarded the western sea lanes in the Atlantic Ocean and the North Sea as the main theater of the war. In the East, naval leaders were primarily concerned with eliminating Russia's naval presence in the Baltic Sea. Yet when Germany extended military and material aid to Finland, German admirals supported this step, hoping to gain a strategic Stützpunkt on the Barents Sea as well as future supplies of raw materials. The interaction of these various strategic considerations produced Germany's complex Baltic policy in 1918.

The war in the East officially ended early in 1918. On February 10 Leon Trotsky had broken off the negotiations at Brest-Litovsk with his famous "no war, no peace" declaration; immediately thereafter he attempted to solicit Western help against the German menace. The Germans, in response, convened a Crown Council in Bad Homburg on February 13. Wilhelm II curtly demanded that the Bolsheviks be "beaten to death," for they only sought to kindle revolution and "create a great workers' hodgepodge." Ludendorff concurred and demanded military operations against Petrograd. The chief of the Admiralty Staff, Admiral Henning von Holtzendorff, declined to take an active part in the discussion. Only the Foreign Office opposed renewed military operations. Kühlmann caustically suggested that the Russians should be allowed to "fry in their own fat." 2 The immediate outcome of this meeting was Operation Faustschlag, set for February 18, 1918. The Germans, having already recognized an independent Finland and an independent Ukraine, rapidly advanced against the disorganized Russian resistance and occupied Narva, Pskov, and Kiev. Lenin agreed to German terms on February $23 .^{3}$

1. The Kaiser hoped to join the Baltic states to Prussia under personal union as well as to place one of his sons (Oskar) on the throne of Finland. The latter plan was thwarted by the German kings and princes who forced Wilhelm to agree to Prince Karl von Hessen as the official candidate. Friedrich Karl was, in fact, elected king by the Finnish Parliament on October 9, 1918, but the unfavorable outcome of the war forced him to decline the invitation. See Winfried Baumgart, Deutsche Ostpolitik, 1918: Von Brest-Litowsk bis zum Ende des Ersten Weltkrieges (Vienna and Munich, 1966), p. 98.

2. Cited ibid., pp. 24-27.

3. Bukharin, Kamenev, and Zinoviev led the fight against acceptance of the BrestLitovsk treaty because of what R. V. Daniels calls the "conscience of the revolution." The Bolshevik Left believed that the existing level of revolutionary élan made it unnecessary to concede to the Germans what the latter had held since 1915: Russian Poland and Courland-Lithuania. 
On March 3 the Bolsheviks signed the German treaty at Brest-Litovsk whereby Russia lost Poland, Courland, and Lithuania. Estonia and Livonia nominally remained under Russian rule, but in fact were subjugated to "German police power." This turn of events greatly pleased Wilhelm: "The Balticum is one and I will become its master and [will] tolerate no opposition. I have conquered it and no lawyers can take it from me!. . Balticum is a whole, in personal union under Prussia's king, who has conquered it! Just as under Frederick the Great [sic]!"4 It is not surprising that the BrestLitovsk settlement did not end German operations in the East.

When civil war erupted on January 19, 1918, throughout Finland, spreading to Helsingfors (Helsinki) by Jantuary $28,{ }^{5}$ Germany opted for active intervention. Apart from the obvious strategic advantage of gaining a new ally against Russia, there was the parallel goal of undermining Bolshevik rule in Russia and of containing the spread of Bolshevism. On February 21 Ludendorff informed the Finnish representative in Berlin, Edvard Hjelt, that he favored granting military aid to Finland, not in order for Germany to acquire additional territory but "to break the power of the Bolsheviks which is threatening all of Europe."' Field Marshal Paul von Hindenburg assured the Kaiser on March 9 of the military necessity of the Finland intervention if Bolshevism was to be contained within Russia's borders. When Admiral von Holtzendorff questioned Ludendorff on May 14 about the goals of the operation, Ludendorff replied that Finland would offer Germany an advantageous strategic base for future military campaigns against Russia. ${ }^{7}$ Ludendorff did

4. Cited in Baumgart, Deutsche Ostpolitik, p. 68.

5. An analysis of German-Finnish relations in this period is beyond the scope of this paper. See especially Baumgart, Deutsche Ostpolitik, and the following works: Der Krieg zur See, 1914-1918 (Frankfurt, 1964), vol. Ostsee III (this is the official German naval history of World War I edited by Rear Admiral Eberhard von Mantey); Walther Hubatsch, "Finnland in der deutschen Ostseepolitik, 1917/18," Ostdeutsche Wissenschaft, 2 (1956): 55 ff.; Fritz Fischer, Griff nach der Weltmacht: Dic Kriegszielpolitik des kaiserlichen Deutschland, 1914/1918 (Düsseldorf, 1964), pp. 606-84; C. Jay Smith, Jr., Finland and the Russian Revolution, 1917-1922 (Athens, Georgia, 1958) ; Gustav Mannerheim, Erimernngon (Zurich and Freiburg, 1952) ; Rudolf Nadolny, Mein Beitrag (Wiesbaden, 1955); Edvard Hjelt, Från handelserika ar, 2 vols. (Helsingfors, 1919); and Rüdiger Count von der Goltz, Meine Sendung in Finnland und im Baltikum (Leipzig, 1920), which appeared in altered form during the Nazi era in a new edition.

6. Cited in Winfried Baumgart, "Unternehmen 'Schlußstein': Zur militärisch-politischen Geschichte des Ersten Weltkrieges," Wehrwissenschaftliche Rundschau, 19 (1969): 220. On February 8, 1918, the German military attaché reported: "It is not only in our interest that the Finnish war of independence be successfully completed, but also that the Red tide, which from Finland threatens Sweden and then Germany, be shored up. A victory by the Red Guards in Finland strengthens the process of disintegration at home. ... [German] rule in Finland offers us the added tremendous military advantage of being near the gates of Petersburg, a situation that offers great military possibilities" (Hubatsch, "Finniand in der deutschen Ostseepolitik," p. 55). I have throughout retained the German "Petersburg" in direct quotations.

7. Ludendorff feared that "a new Russia hostile to Germany could arise"; Russia 
not spell out a further consideration: Finland could become a vital supplier for Germany of metals, paper, and other raw materials. General Paul von Bartenwerffer, chief of the political division of the General Staff, was more explicit: "We must forge weapons for the economic warfare [that will] follow this war." Rear Admiral Adolf von Trotha, chief of staff of the High Sea Fleet, considered the future of the Russian Baltic Sea Fleet "an extremely important question with regard to the army and the nation; a question vital to the future of the navy." Trotha demanded that Germany seize the Russian ships as "war booty." Failure to capture the Russian vessels would constitute "disgrace" for the German navy. ${ }^{\circ}$

The German navy seized the initiative in the Finland undertaking even before the basic political decision had been made whether to grant military aid to that country. On February 28, 1918, Rear Admiral Hugo Meurer left Kiel with about a thousand men of the Fourteenth Mecklenburg Rifle Battalion in order to occupy the Aland Islands. ${ }^{10}$ The Kaiser quickly accepted the consequences of the naval initiative and, on March 2, ordered that the Baltic Division, under General von der Goltz, be sent to aid the Finnish White Army under General Carl Mannerheim. ${ }^{11}$ The final political decision to proceed with the Finland operation was reached on March 12 during a Crown Council in Bellevue Castle. Wilhelm endorsed the military intervention ("police action") for the strategic advantages to be won, for dynastic gains, and for the opportunity to crusade against Bolshevism: "Bolsheviks must be slaughtered because [they are] revolutionary." 12

Between April 1 and 30 the German navy actively took part in the mili-

would constitute a threat in the future regardless of her form of government. See BAMA, F 163/PG 75677, Laufende Marinepolitik: protocol of May 14, 1918, discussion between Ludendorff, Holtzendorff, General Paul von Bartenwerffer, Rear Admiral Walter Baron von Keyserlingk, and Captain Wilhelm von Bülow. The documents cited in this article, unless otherwise noted, are deposited at the Bundesarchiv-Militärarchiv (BAMA) in Freiburg, West Germany.

8. Cited in Baumgart, "Unternehmen 'Schlußstein,"” p. 221. Bartenwerffer to General Rüdiger von der Goltz.

9. BA-MA, F 4055, Kommando der Hochseestreitkräfte: KTB. See the entry for February 27, 1918, containing Trotha's memorandum on the meeting with Admiral von Holtzendorff concerning German naval policy in the Baltic region. The navy had driven the Russian Baltic Fleet out of the Moon Sound Islands in October 1917, and out of Reval (Tallinn) in February 1918. Both admirals were well aware that most of the Russian Baltic Fleet was still based in Finnish ports, especially at its main base, Sveåborg Island, just off downtown Helsinki. Consequently they rightly surmised that the German navy would have to play a major role in the prospective operations against Finland. 64-65.

10. Ostsee III, pp. 349-56. See also Smith, Finland and the Russian Revolution,_pp.

11. Ostsee III, p. 433. Mannerheim, a former Russian army officer, was decidedly anti-German.

12. Cited in Baumgart, Deutsche Ostpolitik, p. 98. 
tary intervention in Finland, transporting troops and supporting land operations with naval artillery. ${ }^{13}$ But it must not be overlooked that this naval operation was of secondary importance. Trotha's eagerness to capture the Russian Baltic Sea Fleet did not reflect official naval policy, as witnessed by the fact that the Germans allowed the Soviet Russians to move their ships from Helsinki to Kronstadt. ${ }^{14}$ Moreover, on April 8 the Kaiser ordered the Baltic special task force to be dissolved at once and the ships returned to the High Sea Fleet. ${ }^{15}$ And Admiral von Holtzendorff refused to allow naval policy in the Baltic Sea to distract from the major objective of interdicting Allied and American shipping in the Atlantic Ocean and the North Sea. Wilhelm fully supported his chief of the Admiralty Staff. As Admiral von Holtzendorff reported, "His Majesty orders reckless submarine warfare as the main objective in the future."16

Germany had achieved her main goals in Finland-in addition to acquiring several million more people to feed, at a time when her own food stocks were dangerously low. She had contained the spread of Bolshevism, gained an ally, acquired a further lever with which to force the Bolsheviks to adhere to the Brest-Litovsk agreement, and attained the prospect of material assistance in the future. But above all, the Finland operation gave Germany a strategically advantageous position from which to advance against the Entente forces stationed in northern Russia.

13. Rear Admiral Meurer left Danzig on April 1 with the battleships Westfalen, Rheinland, and Posen, the cruisers Kolberg, Stralsund, and Nautilus, the auxiliary cruiser $M o ̈ v e$, and numerous supporting craft. He arrived in Hanko three days later, and on April 5 landed 9,000 men and supplies of the Baltic Division. Between April 5 and 11 the navy transported the 3,000-man brigade of Colonel Baron von Brandenstein from Reval to Valkom, about one hundred miles east of Helsinki. The navy also supported military operations on the islands of Utö, Korpo, and Nagu as well as in the coastal cities of Kimito, Ekenäs, and Ảbo (Turku) -all located in the southwest corner of Finland. On April 11 the battleship Rheinland ran upon rock formations in the Baltic Sea and was lost for the rest of the war. See Ostsee III, pp. 380-91.

14. On April 5 Meurer negotiated the Hanko Agreement with the Soviet Russians whereby the latter agreed not to destroy port facilities or ships in Helsinki and to disarm all Russian vessels in that harbor. The Germans, in turn, allowed the Soviet Russians to move their ships to Kronstadt, if they could get them there through the ice. See Ostsee $I I I$, pp. 386-89. The Bolshevik naval forces in Helsinki consisted of four battleships, thirteen destroyers, thirty-nine torpedo boats, and sixteen submarines; there were also four British submarines in Helsingfors. See Smith, Finland and the Russian Revolution, pp. 75-76.

15. BA-MA, F 2022/PG 65984, Admiralstab der Marine: Immediatvorträge, vol. 31, p. 99. Meurer had arrived in Helsinki on April 12; four hundred German sailors took part in the street fighting against Red Guards. Meurer reported on April 30 that he was ready to leave Helsinki and return his naval forces to the North Sea. See ibid., pp. 126-27, for the Admiralty Staff's memorandum of April 25, 1918, for discussion of the Finland operation to be held with Wilhelm II between April 11 and 14.

16. Ibid., p. 99. Decision of April 8, 1918. 
British material aid entered Russia through the ports of Archangel, Murmansk, and Vladivostok after August 1914, and by the summer of 1916 four ships per day were arriving at Archangel alone. By then Great Britain had sent over 1,000,000 tons of coal and 1,500,000 tons of food stuffs and munitions to bolster the Russian war effort. But Russian railroads proved inadequate to expedite these supplies south, and by the end of $1917,12,000$ tons of explosives and 200,000 tons of other vital war materials had accumulated at Archangel. ${ }^{17}$ To alleviate the pressure on this port the British in September 1915 had cajoled the Russians into building a new railroad to the ice-free port of Murmansk. This tie between Petrograd and Kola Bay was hastily constructed by using German and Austrian forced labor (POW's); a single-track spur was ready for use by the fall of 1916 . Yet the line was so shoddily constructed that even the scheduled one train per week in each direction proved to be an overload. Thus in order to secure its war supplies in these northern Russian ports, Great Britain in March 1918 dispatched a battleship and a cruiser, along with supporting craft, to Murmansk. Lenin welcomed this measure as the proper response to German operations in Finland. Both the French and the Americans later underwrote this British initiative by supplying one cruiser each. However, when Lenin invited the British to leave Murmansk after the conclusion of the Finnish Civil War, they refused and in July 1918 occupied Archangel. This step was clearly anti-Bolshevik as well as anti-German. By September there were 15,000 Allied troops in Murmansk and 8,000 in Archangel. ${ }^{18}$ These forces were welcomed by the local Soviet, which was decidedly anti-German. The protection of the stores was of first importance to the Entente powers, but the ultimate goal of the intervention was to restore the eastern front against Germany. And at least the British and the French nurtured further political ambitions in Russia that transcended the initial reason for intervention.

These Allied activities did not escape the attention of German naval leaders. As early as December 27, 1917, the German naval attaché in Stockholm had urged the navy to take a more active part in the Brest-Litovsk negotiations: "Half of the War Office went there. And the Naval Office? Distinguishes itself once again by its absence!" Especially vital for Germany

17. George F. Kennan, Soviet-American Relations, 1917-1920, vol. 2: The Decision to Intervene (Princeton, 1958), pp. 16-17. For the Allied intervention see also Alfred Knox, With the Russian Army, 1914-1917: Being Chiefly Extracts from the Diary of a Military Attaché (London, 1921), vol. 2; Charles Maynard, The Murmansk Venture (London, 1928) ; Henry Newbolt, History of the Great War Based on Official Documents, Naval Operations (London, 1931), vol. 5; Robert Bruce Lockhart, Memoirs of a British Agent (London, 1932) ; Richard H. Ullman, Anglo-Soviet Relations, 1917-1921, vol. 1: Intervention and the War (Princeton, 1961); and John Bradley, Allicd Intervention in Russia [1917-1920] (New York, 1968).

18. Baumgart, "Unternehmen 'Schlußstein,'” p. 174. 
were the raw materials, such as oil, rubber, and hemp, that could be expedited from Russia: "All things that we need as badly as bread."19 Even more urgent were the reports of Rear Admiral Walter Baron von Keyserlingk, chief of the operations division of the Admiralty Staff and military plenipotentiary in Petrograd. He wired the Admiralty Staff from Petrograd on January 17, 1918, that Russia was totally paralyzed and that only external intervention could restore internal stability: "This land is ready to be colonized for the second time in its thousand-year history. . . . The ideal colonizers are the Central Powers." If Germany failed to accept the challenge, Great Britain and Japan would become the new masters of Russia. ${ }^{20}$ On February 14 Keyserlingk again urged German action in "what was once called Russia," recommending military occupation of all "border states." Such a step would provide the Central Powers with a protective wall against the East and with a favorable strategic position from which to exert pressure against the British in India. Especially interesting was Keyserlingk's conclusion that a prerequisite for any further German action in the East was the overthrow of Bolshevik rule in Russia. $^{21}$

These reports were not without effect. On April 24 Holtzendorff expressed his conviction that "one must finally come to the conclusion that Petersburg must be seized." 22 Early in May 1918 the German Foreign Office, which all too often found itself at odds with the military leadership, lent its support to German operations in Finland, expressing the hope that this nation could be "placed on its own two feet, but so that it is dependent on us and remains our tool against Russia." The Foreign Office recommended that Finland be given Murmansk, "so that we can have a policeman also at the most northerly Russian seaport."23

Ludendorff was well aware that the White Finns had designs on East Karelia, lying between Murmansk and Petrograd, and he informed Holtzendorff on May 24 that Finnish possession of a harbor providing direct, ice-free access to the Atlantic Ocean would be "advantageous" for Germany. He

19. BA-MA, Nachlass Vanselow, F 7608. Captain Reinhold von Fischer-Lossainen to Captain Ernst Vanselow, chief of the political department of the Admiralty Staff.

20. BA-MA, Nachlass Keyserlingk, N 161, vol. 1, p. 8. These reports have been published by Winfried Baumgart, "Die militärpolitischen Berichte des Freiherm von Keyserlingk aus Petersburg, Januar-Februar 1918," Vierteljahrshefte für Zeitgeschichte, 15 (1967) : 87-104.

21. BA-MA, Nachlass Keyserlingk, N 161, vol. 1, pp. 21-22.

22. BA-Koblenz, Reichsinstitut für Geschichte des neuen Deutschland, R. 1. Berichte von Holtzendorff, vol. 15. Report of Arndt von Holtzendorff to Albert Ballin, Apr. 24, 1918. These reports to Ballin, head of the Hamburg-America shipping line, were by the brother of Admiral von Holtzendorff. The material is deposited at the federal archive in Koblenz, West Germany.

23. Cited in Baumgart, "Unternehmen 'Schlußstein,'” p. 222. 
asked the admiral to look into this question and to inform the General Staff of the navy's point of view. ${ }^{24}$ On May 28 Holtzendorff answered that he considered a German naval base on the Barents Sea vital to Germany's overall naval strategy, both at present and for the future, adding that this could be realized through Finnish occupation of the Kola Bay area. Germany would help Finland to acquire this region and to expand and improve local port facilities, in return for which Germany would be given indefinite, unlimited use of this strategic region. But Holtzendorff did not believe that this project could be fulfilled in the course of the present war, fearing that such a "distraction" would seriously inhibit the unrestricted submarine campaign against the British Isles. The Atlantic Ocean and the North Sea remained for him the main theaters of the war at sea. Nevertheless, on June 20 he modified his stance, informing Ludendorff that German control of the Murmansk coast "was urgently desired" in the immediate future. German naval strategy necessitated a base on the Barents Sea ; this could best be found in Kola Bay. ${ }^{25}$ Holtzendorff's change in attitude was probably brought about by the initial success of the military offensive in France. Apart from this one instance, he resolutely clung to his point of view that the naval war in the Atlantic must not be weakened by secondary or peripheral operations.

By moving against the Allied forces in Murmansk, Germany hoped to prevent a reopening of the eastern front. But the true nature of the proposed undertaking as a parallel thrust against Bolshevism was clearly reflected in the Kaiser's comments during May 1918. He informed his son Eitel Friedrich on May 21 that if the Bolsheviks did not move against the Allied forces in Murmansk, this would provide Germany with the casus belli to wage a new war against Russia. ${ }^{26}$ In a lengthy marginal comment four days later, Wilhelm defined what he felt should be German policy toward the Bolsheviks. "What are the Bolsheviks?" the ruler asked. "Murder, plunder, theft, looting, destruction of all culture." He said that the Murmansk railroad was essential for the continued existence of the Finnish state, and that it must never be allowed to fall permanently into the hands of the Bolsheviks and their Allied "partners" in the North: "Therefore it is in our interest that Finland gets the railroad and that the Entente is thrown out." The Russians would simply have to be confronted with this reality and be given the alternative of either joining the German campaign against Murmansk or risking renewed hostilities with the Reich: "If diplomacy cannot accomplish this, the sword will." In the final analysis, however, Wilhelm preferred a combined Finnish-Bolshevik advance

24. BA-MA, F 591/PG 69261, Murman. Ludendorff to Holtzendorff, May 24, 1918.

25. Ibid. Holtzendorff's memoranda for Ludendorff, May 28, 1918, and June 20, 1918.

26. Walter Görlitz, ed., Regierte der Kaiser? Kriegstagebücher, Aufzeichmungen und Briefe des Chefs des Marine-Kabinetts Admiral Georg Alexander von Müller, 1914-1918 (Göttingen, 1959), p. 377. 
against the Allies in Murmansk: "We will stand behind them with support and hence both will have to behave!"27 The General Staff shared this position. In a memorandum circulated to naval leaders on June 15, it anticipated the fall of the Bolsheviks "even if it is possible that they will remain at the helm for some time yet." ${ }^{28}$ A Crown Council was announced for July 2, 1918, in Spa in order to give concrete form to these general thoughts and opinions.

Army leaders left no doubt about their desired course of action. The day before the scheduled Crown Council, Ludendorff asked Holtzendorff for an estimate of what support the navy could provide for a Finnish attack on Petrograd. ${ }^{29}$ The following day at the Crown Council in Spa the general announced that the Bolsheviks had declined a German invitation for joint operations against the Allies in Murmansk. The Foreign Office declared that it would try to persuade the Finns to move against the Murmansk railroad; Germany would provide munitions, supplies, and possibly troops: "In any case, an English state [sic] on the Murmansk coast must not be tolerated any longer." ${ }^{30}$ The final outcome of the Council was aptly summarized by the representative from the Foreign Office, Frederic Hans von Rosenberg, in his report for Kühlmann, who was in Bucharest negotiating the peace treaty with Rumania: "During the negotiations with Herr Joffe [the Soviet Russian ambassador in Berlin] we must try once again to convince the Russian government that it should invite us to cooperate with it in operations against the English in Murmansk. Should this [policy] fail, then we must attempt to persuade the Finns to move against the Murmansk coast; possibly German aid in the form of arms and munitions could be promised to them.,"31 The Kaiser enthusiastically endorsed operations against the Allies in Murmansk: "The British must be thrown out of Finland [sic] ... with or without Lenin."32

On July 5 Admiral von Holtzendorff answered Ludendorff's query of July 1 . The chief of the Admiralty Staff judged that much greater resistance should be expected from Bolshevik naval forces in Kronstadt than did the army. The sailors of the Russian Baltic Sea Fleet were, in fact, enthusiastic Bolsheviks at this time. Hence Holtzendorff recommended that, at best, the navy could attempt to gain entrance into Kronstadt Bay and occupy Kotlin Island. Even this limited operation, the admiral argued, depended on continued internal chaos in Russia and on whether Allied forces assisted the Bolsheviks. In any case, the undertaking would have to be carried out at the

27. Cited in Baumgart, "Unternehmen 'Schlußstein," pp. 226-27 (italics in original).

28. BA-MA, F 7549 A7, Akten des Marinemitgliedes der Ukrainedelegation.

29. BA-MA, F 7877, Asto Oberost. Akten betr. Schlußstein-Operation, vol. 1, p. 1.

30. Cited in Hans W. Gatzke, " $\mathrm{Zu}$ den deutsch-russischen Beziehungen im Sommer 1918," Vierteljahrshefte für Zeitgeschichte, 3 (1955) : 85.

31. Cited ibid., p. 91.

32. Cited in Baumgart, Deutsche Ostpolitik, p. 195. 
latest by the end of August because of ice conditions in these northern waters later. The navy required four weeks to prepare the operation. The element of surprise alone could lend success to the campaign, and the admiral suggested a code name, Schlußstein (keystone), to cover the operation. He reminded Ludendorff once again that naval activity in the Atlantic region should receive first priority and that only minor forces could be detached from the High Sea Fleet for an assault on Petrograd. ${ }^{33}$ Ludendorff, in turn, hoped that the navy could break any possible Russian naval resistance and thereafter provision the German troops advancing against Murmansk through the port facilities at Kronstadt and Petrograd. Holtzendorff's reply lent these hopes only lukewarm support.

Nevertheless, Holtzendorff on July 6,1918 , developed a rough battle plan (O-Sache) for the attack against Kronstadt and Petrograd. Vice Admiral Friedrich Boedicker, chief of the First Squadron of the High Sea Fleet, was to be given command of a special naval task force consisting of four battleships of the Ostfriesland class and four cruisers. Holtzendorff requested 1,100 army troops for the seizure of Kronstadt. The force would assemble in utmost secrecy in Libau (Liepaja) with the heavy naval units taking positions near the islands of Lavansaari and Hoogland (Ostrov Moshchny and Ostrov Seiskari), sixty and eighty nautical miles respectively from Kronstadt. Numerous small surprise landings supported by cruisers, torpedo boats, and distant heavy gunfire from the battleships would be made at night on Kotlin Island. The advancing army units could be covered by naval gunpower until they were within twenty kilometers of Petrograd. ${ }^{34}$ This was a sober, realistic operations plan. Though obviously not enthusiastic over what he considered to be an unnecessary diversion of naval forces from the western theater, Holtzendorff was nevertheless willing to lend moderate support to Operation Schlußstein by July 6.

But the Germans had planned without Lenin. Harassed by internal disorders, a vicious civil war, and foreign invasion, ${ }^{35}$ Lenin clearly perceived that his revolution was immediately at the mercy of German military might. He openly admitted at the end of July, "The entire socialist revolution in Russia hinges on the military question." While the Murmansk Soviet, which had defected from the Soviet government, continued to court the Allies, Lenin,

33. BA-MA, F 7877, vol. 1, pp. 2-3.

34. Ibid., pp. 3-4.

35. "The Soviet regime was in a difficult position, struggling with serious internal problems of famine, economic collapse, and counterrevolution, and simultaneously fighting off external attacks from separatists, White Russians, and Allied forces already in Russia. Six separate offensives were being launched against the Bolsheviks on as many different fronts." John M. Thompson, Russia, Bolshevism, and the Versailles Pcace (Princeton, 1966), p. 87. 
in a letter to American workers, hinted at a new alignment: "As much as the English, French, and American imperialistic sharks may rage with fury . . . I would not hesitate for one second to conclude a similar 'agreement' with the German imperialist robbers if an attack by English-French troops [in Murmansk] demanded this." 36 In fact, during the night from August 1 to 2 Lenin sent his foreign commissar, Grigorii Chicherin, to Ambassador Helfferich with a request for German military assistance against the Allied troops in Murmansk. The Bolsheviks did not desire a formal alliance, preferring instead unofficial, parallel military actions by the two "partners." Above all-and this was the key to Lenin's proposal-Germany had to pledge that it would not occupy Petrograd during the joint operation. ${ }^{37}$ Such a step, Lenin feared, could easily result in the overthrow of Bolshevik rule in the former imperial capital. Bolshevik control of the "cradle of the revolution" was the pivotal point of Soviet Russian diplomacy in 1918. In June of that year, in the immediate aftermath of the White victory in Finland, Trotsky had Admiral Shchastny and other naval officers in Petrograd shot because he feared that they planned to facilitate a German move into Kronstadt and Petrograd. The constant preoccupation with a possible German advance into the "cradle of the revolution" partly explains why there was not more resistance to the Whites and Allied interventionists in Murmansk-Archangel, Siberia, the Urals, and Transcaspia in the summer of 1918. Petrograd retained top priority in all strategic deliberations. Finally, Lenin was probably moved to propose this unholy alliance with Germany in the belief that it would be better to cooperate with the Germans than to have them go it alone and take Petrograd in the bargain. Though he obviously could not know of the Kaiser's resolve to wage a new war against Russia if the Soviets refused to move against the Entente in Murmansk, Lenin nevertheless must have perceived the danger inherent in a German advance to the Barents Sea via Petrograd.

The Germans reacted by stepping up intensive planning for Operation Schlußstein. On August 4, 1918, Lieutenant-Commander Rudolph Firle of the Adniralty Staff informed Admiral Reinhard Scheer, chief of the High Sea Fleet, that the army now desired "operations against the Murmansk coast." Army leaders had decided that such an advance was feasible only along the Murmansk railroad and that the "safe possession" of both Kronstadt and Petrograd was vital to the success of the operation. Ludendorff requested one or two battleships to support land operations, and he ruled that Oberost, the German army command in the East, would assume overall command. $\mathrm{He}$ stressed particularly that "peaceful possession" of Petrograd was absolutely

36. Cited in Baumgart, Dettsche Ostpolitik, p. 106; and Baumgart, "Unternehmen 'Schlußstein,'" p. 332 (italics in original).

37. Baumgart, "Unternehmen 'Schlußstein,'” p. 333. 
essential for supplying the advancing German troops; Russian protestations would have to be rejected firmly. The navy was to seize Kronstadt. Admiral Scheer agreed to the project primarily because he wanted to improve relations with the Army Supreme Command and to boost the fighting morale of German naval personnel. $\mathrm{He}$ assigned the battleships Ostfriesland, Thïringen, and Nassau to Boedicker's task force. ${ }^{38}$ Firle informed Holtzendorff on August 5 that Scheer had basically adopted Holtzendorff's plan of July 6 . In addition to the three battleships, the cruisers Stralsund, Strassburg, and Brummer, as well as the tender Blitz, were to be assigned to the formation. Naval command, in contrast to the Finland operation, would rest with the High Sea Fleet rather than with the Admiralty Staff. Various small supporting craft and air reconnaissance forces were also appended to the naval flotilla. It was decided to commence the march at sea from Wilhelmshaven to Libau on August 8; the force would be ready for operations in the Gulf of Finland by August 20, $1918 .^{39}$

Ludendorff lectured naval planners on August 6 concerning his views on the future of Russia. They closely paralleled those expressed by Wilhelm II at the Crown Council on July 2 in Spa. His main theme was that the Bolsheviks had come to the end of the line: "The rule of the Bolsheviks is ready to collapse. . . . Their days are numbered." The general was now prepared to abandon the Foreign Office's policy of working with the Bolshevik leaders in Russia. Ludendorff argued instead that the time had come to restore the monarchy in Russia. In fact, some Russian monarchists had already appealed to Germany for help. ${ }^{40}$ Ludendorff was willing to grant such aid provided that the Russians accepted one stipulation: "Recognition of the Brest peace is the precondition for cooperation." This was the crux of the matter. Russian monarchists consistently stumbled over this stipulation. Ludendorff, however, calculated that they would come to terms once the Bolsheviks had been chased from office. After all, he argued, German occupation of western Russia was merely a temporary military expedient. With the creation of a monarchist Russia, under a federative union such as existed in Germany, at least the

38. BA-MA, F 4055, Kommando der Hochseestreitkräfte: KTB. Entry for Aug. 5, 1918.

39. BA-MA, F 786/PG 77640, Kommando der Hochseestreitkräfte, Sonderverband "Schlußstein." Firle to Holtzendorff, Aug. 5, 1918.

40. Colonel Peter Durnov, former General Staff chief of the Guard Cavalry, contacted the Germans in an attempt to restore the monarchy in Russia under Grand Duke Paul Alexandrovich. A. F. Trepov, Russian premier in November/December 1916, sought German assistance in his efforts to elevate Paul Alexandrovich to the Regency with the help of Generals Yudenich or Denikin. A certain naval lieutenant named Alberts also turned to the Germans on behalf of General Yudenich. All asked for financial and military aid on behalf of various monarchist circles. See Baumgart, Deutsche Ostpolitik, pp. 324 26, n. 80 . 
Ukraine and the Crimea would have to be returned. ${ }^{41}$ Thus he concluded that military action against Murmansk did not aim at German annexation of European Russia or even Petrograd. But until the Russian monarchists were willing to settle on these terms, one was forced to negotiate with Lenin.

Ludendorff's optimism was not entirely out of place. German troops occupied Russian Poland, Lithuania, the Balticum, Finland, the Ukraine, the Crimea, parts of Belorussia, and the Christian parts of Transcaucasia. Moreover, reliable satellite governments existed in Helsinki, Kiev, and Tbilisi. Operation Schlußstein would supplement and thereby consolidate these vast holdings. In addition to expelling the Allies from Murmansk and Archangel, a substantial new success in the East might counter the defeats now being suffered in the West, in the Balkans, and in the Middle East. Seen in this light, Schlußstein was worthy of serious consideration.

The German Foreign Office informed Ludendorff on August 3 that it favored Lenin's request for military assistance against the Allied forces in northern Russia. Ludendorff at first opposed the notion of joint operations with the Bolsheviks, but by August 7 he was prepared to march with them against Murmansk, "in the event that we can occupy Petrograd." He flatly refused to march "shoulder-to-shoulder" with the Bolsheviks but agreed to parallel military actions. The new state secretary of the Foreign Office, Hintze, commented: "Well then! On to the Murmansk coast." Hintze's appointment helped ease the tense relations between the Foreign Office and Army Supreme Command. He as well as Ludendorff favored the military action against Murmansk both for the military necessity of eliminating this Allied front and for the political desirability of terminating Bolshevik rule in Russia. The Bolsheviks agreed to joint military action in a preliminary pact with Germany on August 10, 1918. ${ }^{42}$

Ludendorff was anxious that the army should take the major role in Schlußstein and receive the major credit. He notified Holtzendorff on August 6 that the naval forces set apart for the undertaking were too large. He now argued that the navy should limit its operations to "demonstrations" in Kronstadt Bay, its primary task being to prevent the escape of Bolshevik forces from that port. He further suggested that the army rather than the navy silence Kronstadt's heavy batteries. Finally, he criticized the navy's intention to base its ships in Libau, stating that such action would be detrimental to the required secrecy of the operation. ${ }^{43}$ But Holtzendorff remained adamant. $\mathrm{He}$ informed the general two days later that the forces would be maintained at 22-23.

41. BA-MA, F 7680 A16, Akten des Marinemitgliedes der Ukrainedelegation, pp.

42. Baumgart, "Unternehmen 'Schlußstein," "pp. 335-38.

43. BA-MA, F 7877, vol. 1. Holtzendorff to Admiralty Staff, Aug. 6, 1918. 
present strength in order to be prepared for "any possible incidents." $\mathrm{He}$ reiterated that his forces would be ready to leave Kiel by August 10, 1918; they were being retained in the North Sea in order to maintain maximum security. He also insisted that the navy take along one company of pioneers, and he agreed to send Vice Admiral Boedicker and Lieutenant-Commander Firle to Kovno (Kaunas) on August 10 to discuss the details of Operation Schlußstein with Oberost. ${ }^{44}$

Holtzendorff's caution regarding Bolshevik naval strength was based on intelligence reports received throughout August mainly from officers of the former Russian Imperial Navy. The most detailed of these came in on August 9. It listed the following naval forces in Kronstadt and Petrograd: four battleships of the First Squadron under Captain Dombrovsky, four battleships of the Second Squadron under Rear Admiral Paton, and a reserve of one battleship and four cruisers commanded by Rear Admiral Dmitriev.55 German naval intelligence had apparently not discovered that by this time several destroyers of the Russian Baltic Sea Fleet had been moved through the internal waterways of Russia to the Volga and to the Caspian Sea to fight the White and Allied interventionists. Moreover, Lenin now had some second thoughts about his decision to invite the "German imperialist robbers" to move against Murmansk. He secretly ordered mines to be laid in Kronstadt Bay in order to inhibit German naval movements in this area. ${ }^{46}$ This action openly violated the treaty of Brest-Litovsk and resulted in a lengthy exchange of diplomatic notes between the two "partners."

Under these circumstances the German navy moved cautiously. Boedicker's task force assembled in Kiel between August 10 and 15. The cruisers left that port on August 16, arriving in Libau on August 18, while the battleships remained in the western Baltic Sea. Boedicker bnarded the cruiser Stralsund in Libau on August 18 and assumed command of the naval forces for Operation Schlußstein. ${ }^{47}$

In the meantime, military planning for the proposed action against Murmansk proceeded full speed at Kovno. Firle met with General Max Hoffmann, chief of staff in the East, and other members of Oberost on August 11 and 12. Hoffmann briefly defined the objective of Operation Schlußstein as "occupation of Petersburg and advance against the Entente along the Murmansk railroad." He planned to move against Petrograd with the 5,000-man Baltic

44. Ibid. Holtzendorff to Ludendorff, Aug. 8, 1918.

45. Ibid. Asto Oberost. Akten betr. G. G. Nachrichten "Kronstadt," vol. 1a. Agent report no. 1417.

46. Baumgart, Deutsche Ostpolitik, p. 112. Lenin's order came on August 9, 1918.

47. BA-MA, F 7877, vol. 1, passim. See also BA-MA, Nachlass Hipper, N 162, vol. 8, pp. 25-26. 
Division under General von der Goitz from Finland, with two infantry divisions of 14,000 men from Army Command 6 via Pleskau (Pskov), and with two further infantry divisions from Army Command 60 via Narva. The Tenth Army was to provide another division as reserve. From Petrograd the march would be set forth with three divisions along the Murmansk line to Zvanka. In all, some 50,000 German troops would be deployed against the Allied force of 23,000 in Murmansk and Archangel. The assembly for the march on Petrograd had already begun; it would be completed by August 19 or 20, 1918. Military operations against that city could therefore begin by August 24 . Hoffmann left no doubt that the operation was intended to be more than a military offensive against the Allies when he informed his staff that the military undertaking "is justified as precautionary action against social-revolutionary machinations."48 The navy was to secure the maritime arteries in the Gulf of Finland and the Baltic Sea, prevent a possible escape of Bolshevik ships from Kronstadt, undertake naval demonstrations in front of that city, and, if no resistance was met, occupy the harbor. The navy was also to investigate the possibility of establishing maritime supply routes on Lake Ladoga to provision German troops after the occupation of Petrograd. It was not planned to intern the Russian Baltic Sea Fleet, because only the destroyers (Noviks) were of any military value and because Germany lacked the necessary trained personnel to staff them. Naval leaders were primarily interested in eliminating Russian naval power in the Baltic Sea for all times. Russian scuttling or dynamiting of the ships, as had been the case on July 18 when the Germans tried to seize the Russian Black Sea Fleet, was regarded as the simplest and best solution to the problem.

The German naval estimate overlooked the fact that some of the Noviks, as previously mentioned, were now deep in the heart of Russia on their way to the Caspian Sea. Moreover, two of the Russian battleships and one of the cruisers were new vessels built just before or during World War I; they eventually saw service in World War II as well. Nevertheless, Operation Schlußstein was slowly unfolding.

On August 15 Lieutenant-Commander Ernst von Weizsäcker, Scheer's representative at Army Supreme Command, informed the Admiralty Staff in Berlin that the Kaiser had given his approval to Schlußstein and that the operation was to be executed if the Russians asked for aid or if a political change in Russia appeared imminent. ${ }^{49}$ Two days later Admiral Scheer telegraphed Boedicker that if the Kronstadt naval forces offered no resistance,

48. BA-MA, F 4055. Protocol of Aug. 11, 1918, meeting in Kovno.

49. BA-MA, F 786/PG 77640. Weizsäcker to Admiralty Staff in Berlin, Aug. 15, 1918. 
they were merely to be disarmed. Active resistance was to be met with force and the Russian ships occupied and brought to Germany. ${ }^{50}$ In this O-Befehl, Scheer set the first day of operations for the day on which the battleships left Kiel; by the eighth day of operations the entire flotilla was to be deployed before Kronstadt. ${ }^{51}$ On August 19 Boedicker received orders from Scheer to commence minesweeping operations outside Russian territorial waters in the Gulf of Finland and Kronstadt Bay. The following day Firle informed Boedicker that although the battleships would still remain in Kiel, the pioneer troops requested by Holtzendorff had begun their march to Libau. ${ }^{52}$ The navy announced on August 20 that the task force had been officially formed as a tactical entity consisting of the battleships Ostfriesland, Thïringen, and Nassau, the cruisers Kolberg, Regensburg, Strassburg, and Stralsund, and the tender Blitz. Sixteen torpedo boats and minesweepers stood by at Libau and Danzig. ${ }^{53}$ The next day the Army Supreme Command reminded the navy of the operation's objective: "to establish in Russia against the Bolsheviks the restoration of orderly conditions, if necessary by re-establishing monarchical rule under a tsar and supporting this movement through German aid in the form of German troops."

But diplomatic negotiations, which revolved around the thorny question of German occupation of Petrograd, continued to delay execution of Schlußstein. Admiral Scheer informed Firle on August 21 that the battleships were to be returned to the North Sea from Kiel. The first day of operations would now be the day on which they left Wilhelmshaven; the force could be deployed before Kronstadt on the eleventh day of operations. In any case, twenty-fourhour readiness was maintained. All supporting craft remained in the Baltic Sea either at Libau or at Danzig. Scheer warned Firle that the Bolsheviks would probably attempt to scuttle their ships if German naval forces entered Kronstadt Bay: "We must therefore operate with the element of surprise in order to save them." 55 Was the admiral now contemplating seizure of the Russian Baltic Sea Fleet? German minesweeping operations in the Gulf of Finland continued.

By the end of August, the dragging diplomatic negotiations between Berlin and Moscow brought Schlußstein to a complete halt. Hintze insisted on the completion of the German-Soviet supplementary pact to the BrestLitovsk peace treaty before proceeding with military operations in Murmansk.

50. Ibid. Scheer to Boedicker, Aug. 17, 1918.

51. BA-MA, F 7877, vol. 1, pp. 29-30.

52. Ibid., pp. 27-28.

53. Ibid., pp. 53-60.

54. Ibid., vol. 1a, p. 26. Major Wachenfeld of the Army Supreme Command to Admiral Scheer (italics in original).

55. Ibid., vol. 1, pp. 32, 34. 
The supplementary agreement was delayed by the problem of German occupation of Petrograd. It was finally signed on August 27, 1918. In a secret exchange of notes between Hintze and Joffe, Germany agreed not to use Petrograd as a base of operations for Schlußstein. These diplomatic wranglings provided Lenin with much-needed breathing space and greatly irritated German military and naval planners. On August 29 Boedicker caustically reported: "Nothing new from Kronstadt." "5o Hoffmann spoke of "boring work" and hoped that the Allied troops might advance against Petrograd and thereby force the issue: "Then we would have to attack. It is too boring here."57 Prince Leopold of Bavaria, the nominal commander of Oberost, expressed similar restlessness. ${ }^{68}$ Yet nothing happened. Boedicker was ordered to return to the North Sea on September 1 because execution of Schlußstein seemed "unlikely." Further withdrawals of naval forces from the Baltic Sea were contemplated. Schlußstein appeared to be in deep freeze.

This situation was drastically altered in September when news reached Germany that Lenin had been seriously wounded by an assassin on August 31. Ludendorff informed Oberost on September 4 that Schlußstein was to be ready for execution at a moment's notice. The following day the navy received word from Army Supreme Command that because of the "very serious, muddled situation in Petersburg" Oberost had been informed that Schlußstein was definitely "on" again. ${ }^{59}$ The navy was back on its eleven-day combat readiness alert $^{60}$ The immediate outcome of this renewed activity was an inspection tour of Lakes Ladoga and Onega by a joint German-Russian military committee in order to determine use of the lakes for possible maritime provisioning of the proposed joint march to the Murmansk coast. ${ }^{61}$

But Germany's position in Europe was crumbling on all fronts. Weizsäcker had noted already on September 12 that the naval operations against Kronstadt would probably have to be canceled because the troops would be needed against Rumania, which had resumed hostilities against Germany. ${ }^{62}$ Two days later, Ludendorff officially informed Oberost that Schlußstein would

56. Ibid. Boedicker to Scheer, Aug. 29, 1918.

57. Karl Friedrich Nowak, ed., Die Aufzeichmungen des Generalmajors Ma.r Hoffmann, 2 vols. (Berlin, 1929), 1:205-6. Entry for Aug. 19, 1918.

58. Baumgart, "Unternehmen 'Schlußstein," p. 352.

59. BA-MA, F 4055/PG 64725. Entry for Sept. 5, 1918.

60. See BA-MA, Nachlass Levetzow, N 239, box 22, vol. 1. See also Kriegstagebuch der Seekriegsleitung, pp. 23-24.

61. Baumgart, "Unternehmen 'Schlußstein,'” p. 354.

62. "The Papers of Ernst von Weizsäcker," letter of Sept. 12, 1918, to his father Carl von Weizsäcker, minister president of the Kingdom of Württemberg. These papers are being prepared for publication by Professor L. E. Hill of the University of British Columbia, to whom I am indebted for permission to use the material. 
have to wait until "accounts with Rumania are settled."03 The troops allocated for Schlußstein were now urgently needed to bolster the Balkan and western fronts. On September 21 the navy received notice that the military situation in the West forced the cancellation of Schlußstein. ${ }^{64}$ Six days later the Army Supreme Command ordered that all preparations for Schlußstein be broken off immediately. ${ }^{65}$ The navy canceled its preparations on September 29, retaining only a few torpedo boats on patrol duty in the Gulf of Finland.

The Allied and Associated Powers had hoped to offset German operations in Finland by occupying Murmansk, and to prevent the spread of their stores into Central Russia and ultimately into German hands by moving into Archangel. President Woodrow Wilson shared British and French hopes of reopening the eastern front, possibly with the help of Czechoslovakian troops in Siberia, and therefore underwrote the Allied presence in northern Russia. Germany had initially planned to counter this threat by using Finnish troops; German soldiers and statesmen had promised to help Finland acquire Karelia, provided that she adopted a monarchical form of government, preferably headed by a German prince. ${ }^{66}$ But on July 2 this illusion gave way to the more realistic, though highly daring, plan of a joint German-Soviet advance. Both the very real danger posed by Allied troops in Murmansk and the independence of the local Soviet compelled Lenin to seek a military pact with Germany. This unholy alliance suffered shipwreck over the question of German occupation of Petrograd. German military planning was completed by August 24. The 50,000 German soldiers were sufficient alone to expel the 23,000 Allied troops in northern Russia. And Lenin rightly feared that a German occupation of Petrograd would spell the end of Bolshevik rule, certainly there and perhaps in other areas of Russia as well. He therefore delayed execution of Operation Schlußstein by dragging out negotiations with Germany and by secretly mining Kronstadt Bay.

It is evident from the documents that Germany also wanted to end Bolshevik rule in Russia. This was the second, or political, aim of Operation Schlußstein. Military and naval leaders were agreed on this. Wilhelm II gave the plan vociferous support. General Hoffmann was decidedly anti-Bolshevik by the end of August 1918, and his troops would have marched through Petrograd-with or without Lenin. There can be little doubt concerning the outcome of such an operation.

The German activity in the eastern Baltic region in 1918 probably en-

63. Baumgart, "Unternehmen 'Schlußstein," p. 411.

64. BA-MA, Nachlass Levetzow, N 239, box 22, vol. 1, pp. 23-24.

65. Baumgart, "Unternehmen 'Schlußstein," " p. 411.

66. See Hubatsch, "Finnland in der deutschen Ostseepolitik," pp. 76-77. See also note 1 above. General Mannerheim was elected regent in November 1918. 
couraged, if not caused, the Allied and Associated Powers to opt for military intervention in Russia. In fact, both Germany and the Allies, though agreeing that Lenin's regime could not, or should not, survive, nevertheless were determined that the main enemy in World War I should not reap advantages from Lenin's demise. This helped him stay afloat during 1918. On the Allied side, this is reflected in the considerable difference between the motives which prompted the Murmansk intervention in March 1918, with Lenin's permission, and those which prompted the Archangel intervention in July 1918. On the German side, it is reflected in the difference between the initial hesitation over intervention in Finland during the first three months of 1918, and the boldness with which the far more ambitious project of the seizure of Petrograd, the "cradle of the revolution" as well as the capital of the tsars, was contemplated in August and September 1918.

In the final analysis, Germany, by its commitment to the goal of total victory in both the East and the West, brought about the collapse of Bismarck's Reich and the disintegration of the Habsburg and Ottoman Empires. Perhaps the most advantageous strategy for Germany in January and February 1918 would have been the immediate invasion of the Ukraine, the Balticum, and Finland, but the Army Supreme Command was the prisoner of the theory that it must knock the West out in 1918. Perhaps domestic conditions in Germany allowed army leaders no other choice. Yet it is interesting to conjecture what might have happened if Germany had attacked Petrograd in September 1918. In retrospect, Operation Schlußstein is one of those elusive historical "ifs": if the operation had been planned earlier, if it had not been delayed by the Foreign Office, if it had been executed as planned, if Rumania had not re-entered the war at this critical juncture, and so on. It would clearly have had a major effect on the outcome of the Russian Civil War, and possibly on the subsequent role of Russia in world history. General von der Goltz thought that he had caught the significance of the hour: "A moment of world historical importance was passed up." ${ }^{07}$

67. Cited in Baumgart, “Unternehmen 'Schlußstein,'” p. 413. 